\title{
Commentary Haemodialysis and peritoneal dialysis patients admitted to intensive care units
}

\author{
Nishkantha Arulkumaran, John B Eastwood and Debasish Banerjee
}

Renal and Transplantation Unit, St George's Hospital, Blackshaw Road, Tooting, London SW17 0QT, UK

Corresponding author: Debasish Banerjee, debasish.banerjee@stgeorges.nhs.uk

Published: 31 May 2007

This article is online at http://ccforum.com/content/11/3/133

(c) 2007 BioMed Central Ltd
Critical Care 2007, 11:133 (doi:10.1186/cc5914)

100 patients had an ICU bed requirement of 32 days; that is, about 1 month per year. At this admission rate, one ICU bed will support a population of about 1,200 dialysis patients. It was surprising, however, that there was no increase over the 9 years despite the known increase of about $50 \%$ in the number of dialysis patients over the same period.

Dialysis patients in ICUs were twice as likely as other patients to have had cardiopulmonary resuscitation before admission to ICU. This is consistent with the known increased prevalence of cardiac arrhythmias in patents with end-stage renal disease [8]. It is interesting that relatively few dialysis patients were admitted with complications of congestive heart failure, or with acute coronary events. It is possible that these patients were in practice admitted to coronary care units rather than ICUs. Clearly, any future study of critically ill dialysis patients in hospital must include those admitted to coronary care units and high-dependency units (HDUs).

The study by Hutchison and colleagues demonstrates, in dialysis patients, an ICU mortality of $26 \%$ and an 'in-hospital' mortality of $45 \%$. These are encouraging figures when one considers that patients in the dialysis group were considerably sicker, with higher APACHE (Acute Physiology and Chronic Health Evaluation) II scores (24.7 versus 17.2) than other ICU admissions. The median length of stay in ICU of the dialysis group, however, was very similar to that of the non-dialysis group (1.9 days versus 1.8 days) This length of stay of 1.9 days is very much at the lower end of the range shown in Table 1. It is interesting, too, that the dialysis group had both a longer overall hospital stay and a higher death rate after leaving ICU. These data suggest that the dialysis patients may be leaving ICU too early, or there may perhaps be a perception in ICUs that renal wards are better equipped than general wards to receive patients from ICU, and may be transferring them too early.

$\mathrm{HDU}=$ high-dependency unit; ICU = intensive care unit. 
Table 1

Studies on ICU admissions in patients with end-stage renal disease on maintenance haemodialysis

\begin{tabular}{|c|c|c|c|c|c|c|}
\hline Reference & $\begin{array}{c}\text { Number of } \\
\text { patients }\end{array}$ & $\begin{array}{c}\text { Mortality } \\
\text { in ICU } \\
\text { (percentage) }\end{array}$ & $\begin{array}{c}\text { Mortality } \\
\text { in hospital } \\
\text { (percentage) }\end{array}$ & $\begin{array}{l}\text { Length of } \\
\text { stay in ICU } \\
\text { (days) }\end{array}$ & $\begin{array}{c}\text { Age } \\
\text { (years) }\end{array}$ & $\begin{array}{c}\text { Severity } \\
\text { score }\end{array}$ \\
\hline [3] & 93 & 9 & 16 & 2 days & 66 & 64 (APACHE III) \\
\hline [2] & 57 & 11 & 14 & 5 days & 58 & 64 (APACHE III) \\
\hline [5] & 38 & 22 & 38 & 6 days & 45 & 22 (APACHE II) \\
\hline [4] & 92 & 28 & 38 & 6 days & 63 & 44 (SAPS II) \\
\hline [1] & 3,420 & 26 & 45 & 1.9 days & 57 & 25 (APACHE II) \\
\hline
\end{tabular}

APACHE, Acute Physiology and Chronic Health Evaluation; ICU, intensive care unit; SAPS, Simplified Acute Physiology Score.

The fact that the number of dialysis patients admitted to ICUs did not increase during the 9 years could be due to the reluctance of critical care physicians to accept such patients on account of their high morbidity and mortality, or possibly because some ICUs have insufficient facilities for dialysis and haemofiltration. The study of Hutchison and colleagues showing that dialysis patients have similar ICU mortality and length of stay to those of other ICU patients indicates that there should be no reluctance to take such patients. Furthermore, there is a clear need for more HDU beds to assist in the safe transfer from ICU to general ward. Interestingly, a study from a French collaborative group over a period of 4 years also showed no increase in the number of dialysis patients admitted to ICUs.

In conclusion, this nationwide study over 10 years shows that dialysis patients generally fare well in ICUs but less well after leaving such units. Resources need now to be diverted to the general raising of standards of HDUs, to ensure the safe return of dialysis patients to renal wards - or perhaps large renal units need their own HDU.

\section{Competing interests}

The authors declare that they have no competing interests.

\section{References}

1. Hutchison CA, Crowe AV, Stevens PE, Harrison DA, Lipkin GW: Case mix, outcome and activity for admissions to intensive care units requiring chronic renal dialysis: a secondary analysis of the ICNRC Case Mix Program Database. Critical Care 2007, 11:R50.

2. Clermont G, Acker CG, Angus DC, Sirio CA, Pinsky MR, Johnson JP: Renal failure in the ICU: comparison of the impact of acute renal failure and end-stage renal disease on ICU outcomes. Kidney Int 2002, 62:986-996.

3. Dara SI, Afessa B, Bajwa AA, Albright RC: Outcome of patients with end-stage renal disease admitted to the intensive care unit. Mayo Clin Proc 2004, 79:1385-1390.

4. Manhes G, Heng AE, Aublet-Cuvelier B, Gazuy N, Deteix P, Souweine B: Clinical features and outcome of chronic dialysis patients admitted to an intensive care unit. Nephrol Dial Transplant 2005, 20:1127-1133.

5. Uchino S, Morimatsu H, Bellomo R, Silvester W, Cole L: Endstage renal failure patients requiring renal replacement therapy in the intensive care unit: incidence, clinical features, and outcome. Blood Purif 2003, 21:170-175.

6. Edwards NC, Steeds RP, Ferro CJ, Townend JN: The treatment of coronary artery disease in patients with chronic kidney disease. QJM 2006, 99:723-736.

7. Herzog CA: How to manage the renal patient with coronary heart disease: the agony and the ecstasy of opinion-based medicine. J Am Soc Nephrol 2003, 14:2556-2572.

8. Herzog CA, Li S, Weinhandl ED, Strief JW, Collins AJ, Gilbertson DT: Survival of dialysis patients after cardiac arrest and the impact of implantable cardioverter defibrillators. Kidney Int 2005, 68:818-825.

9. Rocco MV, Yan G, Gassman J, Lewis JB, Ornt D, Weiss B Levey AS; HEMO Study Group: Comparison of causes of death using HEMO Study and HCFA end-stage renal disease death notification classification systems. The National Institutes of Health-funded Hemodialysis. Health Care Financing Administration. Am J Kidney Dis 2002, 39:146-153. 